Meta

Journal des traducteurs

Translators' Journal

\title{
On Translatibility from English into Arabic: Words and Beyond
}

\section{Ali Gadacha}

Volume 51, numéro 1, mars 2006

URI : https://id.erudit.org/iderudit/012992ar

DOI : https://doi.org/10.7202/012992ar

Aller au sommaire du numéro

\section{Éditeur(s)}

Les Presses de l'Université de Montréal

ISSN

0026-0452 (imprimé)

1492-1421 (numérique)

Découvrir la revue

Citer cet article

Gadacha, A. (2006). On Translatibility from English into Arabic: Words and Beyond. Meta, 51(1), 36-50. https://doi.org/10.7202/012992ar

\section{Résumé de l'article}

L'article traite de la traductibilité à partir d'exemples recueillis durant un cours de traduction (version). L'auteur envisage les problèmes que les étudiants de fin d'études à l'Institut des Langues (Tunis) sont susceptibles de rencontrer lors du passage de l'anglais à l'arabe. Cet article rend compte des valeurs, des sentiments et des jugements que suscitent les mots - unités irréductibles du langage qui ne relèvent pas d'une dénotation et du codage strictement linguistiques. En raison de leur force illocutoire, les mots, formules et expressions ne peuvent être transposés tels quels sans aucune perte de sens en amont. Il convient donc d'étudier les situations dans lesquelles on peut transcender les barrières qui nous enferment - qu'elles soient psychologiques, linguistiques ou culturelles - afin d'opérer les choix les meilleurs. Pour ce faire, le traducteur doit défier les modes d'appréciations orthodoxes et appréhender le mot - surtout s'il est fortement connoté - comme unité de discours à part entière. Seule la primauté de l'interprétatif permet donc de saisir le pouvoir quasi magique des mots, d'où l'intérêt d'une vision plus large.
Ce document est protégé par la loi sur le droit d'auteur. L’utilisation des services d’Érudit (y compris la reproduction) est assujettie à sa politique d'utilisation que vous pouvez consulter en ligne.

https://apropos.erudit.org/fr/usagers/politique-dutilisation/ 


\title{
On Translatibility from English into Arabic: Words and Beyond
}

\author{
ALI GADACHA \\ University Joseph Fourier, Grenoble, France \\ gadacha_ali@yahoo.fr
}

\section{RÉSUMÉ}

L'article traite de la traductibilité à partir d'exemples recueillis durant un cours de traduction (version). L'auteur envisage les problèmes que les étudiants de fin d'études à l'Institut des Langues (Tunis) sont susceptibles de rencontrer lors du passage de l'anglais à l'arabe. Cet article rend compte des valeurs, des sentiments et des jugements que suscitent les mots - unités irréductibles du langage qui ne relèvent pas d'une dénotation et du codage strictement linguistiques. En raison de leur force illocutoire, les mots, formules et expressions ne peuvent être transposés tels quels sans aucune perte de sens en amont. Il convient donc d'étudier les situations dans lesquelles on peut transcender les barrières qui nous enferment - qu'elles soient psychologiques, linguistiques ou culturelles - afin d'opérer les choix les meilleurs. Pour ce faire, le traducteur doit défier les modes d'appréciations orthodoxes et appréhender le mot - surtout s'il est fortement connoté - comme unité de discours à part entière. Seule la primauté de l'interprétatif permet donc de saisir le pouvoir quasi magique des mots, d'où l'intérêt d'une vision plus large.

\section{ABSTRACT}

This paper is an attempt to investigate the current problems the students graduating in English at the ISLT' are likely to encounter when setting out to render English into Arabic. My teaching experience with them was beneficial, albeit quite short (one year-long only, 2000-2001). The material gathered, on the other hand, was wide-ranging and, better still, so provocative that I readily agreed to venture onto dangerous ground. ${ }^{2}$

Studies in the past have often failed to delve deep into possible meanings and extend beyond traditional boundaries so as to assess the scope of words and explore the meaning potentials. Recent advances in the literature argue that translators should be sensitive to the losses and gains of cultural elements and assess the "weight" of these elements in the source text in order to bring about the same/similar effects.

It is true that loss of meaning is inevitable and the transference to the translator's language can only be approximate (Newmark 1988, 7). The current trend in translation theory is to explore situations to make it possible to transcend linguistic as well as cultural barriers. Translators will continue to reproduce only restricted facets of meaning so long as they do not vanquish ordinary processes of thought and approach the words in the SL text as units of discourse. I make no pretence at being able to offer definitive solutions. This account aims at identifying the potentially problematic areas in translating English into Arabic. The sense of new in this experience embodies a larger vision, apparently a different quality of recognition since the focal interest is laid on the interpretive weight of words as constituent parts of the act of communication.

\section{MOTS-CLÉS}

translatability, words, connotation, meaning potentials, interpretive weight 


\section{Introduction}

The following preliminaries are worth stating beforehand: (1) It is not difficult to document hesitancy in translation, though we seldom identify the causes at first sight. (2) The translation process, by lying at the heart of several fields, i.e. anthropology of language, ethnography of speaking, sociology, rhetoric, stylistics, pragmatics, etc., raises intricate problems which no single field can sort out by itself.

It will be my endeavour in this to locate the major areas of potential failure. The task is to take notice of the semantic load of words and assess their degree of translatibility. In addition, I shall demonstrate under what circumstances students fail to cope with the management whether of the phrastic format or semantic substance of a text ${ }^{3}$ and the consequences this entails on the translating process.

In collecting data, my approach was simply to accumulate examples in an exhausive manner. The data include the translation of texts - extracts from famous papers and excerpts from bestsellers and classics - by the students, transcriptions of a large number of discussions whether with the students about why and how a text has to be translated in a given way or with colleagues who have a long teaching-experience. I went several times over the texts selected, which enabled me to shed light on the circumstances leading to mistranslation. Then, the notes I had written down at random besides miscellaneous readings on the subject proved an excellent supplement. The exercise took me several months to draft and address the question of translatability as a key concept for understanding encounters between cultures.

\section{Analysis}

To start with, I would like to ascertain the extent to which the students are aware of discourse both cross-linguistic and cross-cultural. Straightforwardly, we may say that students seem to attach far more importance to surface phenomena than to the import of the different elements of discourse. Thus, in the text "Rise in Price of Oil Starts to Hurt Asia" (Appendix I) when asked to compare starts to hurt in the title to is starting to hurt in sentence (1), they will say that while the former is simple present, the latter is continuous. A corollary of this is that students show they are perfectly able to draw the surface aspectual distinction yet unable to capture the subtleties concomitant with the change in aspect be they semantic, stylistic or pragmatic.

Sentence (1) Appendix I:

"The surge in oil prices is starting to hurt Asia, increasing energy costs in many economies and raising fears that growth may slow just as much of the region is rebounding impressively from the financial crisis and recession of 1997 and 1998."

In terms of phase structure perfective starts seems to refer to the event as a whole whereas imperfective is starting points to the process phase only, the prestate more precisely. Thanks to the semanticism of the verb to start, as intrinsically inchoative and indicative of both event and state, the simple present here is not an extratemporality case with unlimited duration. Indeed, the launching point of the crisis is predicated as close and eminent. This example illustrates how predicate phrase, event notion (lexical choice of the verb) and aspect display some coherence (cf. Schramm 1996). Aspect in the case in point constrains lexical choice and encodes point of view. In consequence, while neutral and objective rise + simple present is best suited to this 
'matter of fact' the surge in oil prices + be-ing is predicated as hurting Asia (phase I). The writer picks up surge as the appropriate choice to tell us her/his point of view. In fact, the cooccurence of neutral and objective rise/perfective and subjective surge/ imperfective are revelatory of the writer's persepective.

Therefore, aspect by itself does not suffice to cope with meaning potentials. Change in aspect does alter meaning; but the converse is not always true. The example quoted above is reminiscent of CNN's campaign against terrorism. In America strikes back (title of the program) the government is stepping up the campaign to wage war against terrorism: the preparations to strike back are well under way. A few weeks later, the situation has changed: the war has broken out and soldiers have joined battle; yet, the title, America strikes back, is kept unchanged, hence the perfective and imperfective might, in circumstances such as these, be viewed as alternate means of expression. In fact, it is the context which attributes, and even defines, the meaning.

Widdowson $(1979,16)$ states that "the best - perhaps the only way - of characterizing different registers is to discover what rhetorical acts are commonly performed in them, how they combine to form composite communication units, and what linguistic devices are used to indicate them." Since "the conventions of use associated with particular types of discourse very often override linguistic indicators of rhetorical acts," one has to cope with the sentence as a proposition and demonstrate how aspect indicates the rhetorical act. Consider this:

"Lake Geneva is becoming severely deoxygenated during the summer months, owing to the hydroelectric dams built in the upper Rhone" (Upjohn 2002, 1 Unit 7).

For being foremostly descriptive, informative, factual and objective the simple here is excluded. Vb-ing seems to expressly encode the concern and intentions of the addresser. No sooner does the addressee (the translator-reader) realize that vb-ing conveys subjectiveness and encodes an attitude, s/he transcends ordinary processes of reasoning. The adressee is aware of both the rhetorical act, i.e. the warning, and the illocutionary act, i.e. the call to join in the protest campaign. It is impossible to infer the illocutionary meaning here unless one ventures forth and interprets the statement. It might be argued, by analogy, that aspect is as helpful a linguistic device to guess the act of rhetoric as ordering (fronting/foregrounding the topical idea) and that the simple maps onto "the given" (what is objective) and the continuous onto "the news/ topic" (the subjective) (cf. Halliday 1985, 59 and Gadacha 1998, 163).

On the other hand, the probe into how 'attention orientation' operates, i.e. what orients the translator socially, cognitively and affectively, may enlighten the reader. It seems that the focus is instantly laid on surface phenomena and seldom extends beyond. Of the overwhelming majority who, unperturbed by problems of discourse, seem virtually indifferent to the concomitant effects only a few students were alert to such important features as ordering and position of occurrence, i.e. that starts appears in the title while is starting shows in the opening sentence.

In other words, students seldom provide satisfactory answer when asked to distinguish between verb forms in terms of rhetorical effects. Needless to say that aspect and syntactical details as a whole in keep with wider phenomena which are not necessarily linguistic. Obviously, titles are carefully worded because they are meant to catch the reader's eye and impel her/him toward the last line. 
While the title heads the text of an article or a book the very first sentence initiates the whole task and lays the foundation stone. The kickoff takes on a particular importance whether in playing football or writing an essay. Consider the following where the first line is paralled nowhere else in the text in that it carries the author's main intentions and, better still, in keeps with the quintessence of the Kafkaesque school. Though pared to essentials, so as to gain in elegance and simplicity, the opening sentence is foremostly informative if not provocative.

Sentence (1) Appendix III:

"As Gregor Samsa awoke one morning from uneasy dreams he found himself transformed in his bed into a gigantic insect."

Apart from the declarative non-elliptical mode, the first two sentences (Appendix I and Appendix III) bring the issue at stake to the forefront. As a rule, words and expressions showing up first are loaded with particularly significant meanings. ${ }^{4}$

Sentence (1), incidentally, turns out to be as long as paragraph (1) (Appendix I). Regardless of whether this is indicative of the author's fondness of long strings of phrases or not, the translation must minimally invoke notions of the image conveyed by the words in the SL. Mistranslation often arises from the failure to seize the image or illocutionary force of the very first words. Viewed from this perspective, the word surge and the problems it raises should be investigated in some details as they are a good example of the difficulties the students come up against when they set about rendering the text "Rise in Prices of Oil starts to hurt Asia" into Arabic.

First of all, the use of surge embodies a choice. Any word selection presupposes the existence of a set of alternatives or oppositions. In fact, lexical items in a language act as semiotic systems, which implies the recognition of words as encoding meaningful oppositions. The shift from an item-centred view of language to one which is structure-centred is total when individual sounds, words or parts of sentences have no linguistic significance in themselves but have significance only as they contrast and combine with other items in the patterns of a linguistic system.

Translators are led astray when they take lexical equivalence for granted ${ }^{5}$ and treat words in isolation regardless of text, co-text and context altogether. ${ }^{6}$ Having scanned the paradigm of the Arabic stock of words likely to convey surge, I realized that the exact equivalent for surge is not properly available. /irtifa/ (rise) which springs first to the mind of all students is too candid and generic a gloss in Arabic, therefore not workable. For /irtifa/ is deliberately equivocal whereas surge unquestionably evocative of an abrupt changeover, hence the threat of semantic distortion is looming large. Unless connected to an adjunct of some sort, the Arabic word would be lacking in the illocutionary force its English counterpart surge conveys by itself. ${ }^{7}$ Students are bound to fail to capture the subtlety of surge so long as they labour under the illusion of literal translation. The word-for-word technique in this case is unrewarding. The only way, in my view, to make up for the loss in meaning and effect is to resort to the dialect, ${ }^{8}$ no matter what purists would say. Equivalent words or expressions, drawing on the same line of thought and perception, hence evoking the same/similar/close images, may be readily available in daily speech. The latter displays flexibility of language and user and evidences viability of the processes and mecanisms involved to make it possible for the speaker to express her/himself satisfactorily (For a discussion on speech/writing dichotomy, cf. Gadacha 1991, 42-45). Whatever one might argue, 
the following translation for its connotational effects must supersede: /laswam chiilit nar/ (prices caught fire).

Immediately after the surge case, a further lexical challenge awaits the students. This time the trouble seems to result from the students themselves rather than from the 'hesitancy of the language' (cf. Gallagher 1968 in Gadacha 1991, 73-75). While only one single Arabic word has been suggested in substitution for surge, at least three words stand in for oil: /naft/, /mahruqat/, and /bitrul/. Only half the students are aware of their proper use. To the other half all three words diverge but slightly, hence the failure to use the right word. In fact, /mahruqat/ means fuel, /bitrul/ means petrol or gas, gasoline and /naft/ oil or petroleum as it flows from the underground...

Although such students may well know what the acronym OPEC ${ }^{9}$ stands for, they fail to identify /naft/ as the right choice. Since its decisions affect, and are likely to alter, world economy, OPEC has made the circulation of /naft/ gain wider acceptance. No streneous effort is needed here to guess the right equivalent simply because the use of /naft/ is so current.

But not all that wins general consensus fits, not even when it looks authentic and so current. To turn rebounding impressively into /tachhadu nuhudhan mudhichan/, as most of the students have done, is a bit awkward since it does not convey the sense of boost and impetus the economies of the region seem to have received. More importantly, the Arabic translation is lacking in metaphorical strength as it neither conveys the sense of rapidity nor evokes the image in which the ball bounces back after hitting the ground. In order to ascertain the extent to which the Arabic translation suggested above is rather flat and pallid one simply has to attempt back translation. In other words, the translator here fails the transferral of literal and figurative meanings so long as /qafzatan/ (a jump), as the lesser evil, does not supersede /nuhudhan/.

Words have the potential of expanding the boundaries of language and its concomitants. In other words, words are not there simply to denote persons, objects or even concepts; on the contrary, they do connote ideas and invoke images. Each speaker or writer uses the word(s) as s/he feels and each listener or reader interprets it her/his own way. By corollary, literal translation of metaphors is hardly ever rewarding. Only when s/he draws a visual image of each word, and only then, can a translator attempt solutions by putting the particulars of a text into focus and interaction so as to reproduce the whole metaphorical effect.

Economists, analysts and journalists are impressed by the giant strides the Asian economies are making. The impact is such that rebounding by itself does not suffice, though the metaphor is quite strong especially when pictorially visualized. That is why impressively alongside rebounding is neither tautological nor decorative, but rather hyperbolical. Poets, novelists and writers who make use of hyperbolies are usually rather prone to exaggeration. Yet, the sheer exuberance of the description as expressed in the text is a marker of singularity. The choice can be interpreted as encoding a subjective attitude (since the writer could have chosen to encode an objective attitude). Subjectivity is part and parcel of the whole translation process, save in scientific discourse. Subjectivity is a dangerous necessity and a necessary danger. ${ }^{10}$ The meaning of words is not simply a matter of objective facts; a great deal of it is subjective on account of the interpretive weight. The paradox holds so far as the translator does not adapt.

Probing the mysteries of words is an act of interpretation. Situational or pictorial thinking is the foundation of all interpretation; pictorial thinking subsumes the pictorial 
visualization of words as single entities and as they interact with the rest. Translators must therefore balance the individual word with the whole of a work. Through this practice of constantly balancing the dynamics of words as they shift across the text, the translator takes associative and contextual meanings into account. As can be seen from the text of D.H. Lawrence, translators cannot approach the text superficially, i.e. on a linear basis. Unless words are connected to text and then to context the whole undertaking would seem foredoomed. ${ }^{11}$

Nonetheless, the word itself by virtue of its creative power, whether as a rhyme word, switch word, alliterative word, or a marker of craft-concern, etc. allows us to explore new ways of meaning. In that respect, the translation process affirms the 'how' and not simply the 'what' of reading and understanding.

"As they descended, they heard the Minster bells playing a hymn, when the hour had struck six.

'Glory to thee my God this night

For all the blessings of the light'

So, to Ursula's ear, the tune fell out, drop by drop, from the unseen sky on to the dusky town. It was like dim, bygone centuries sounding. It was all so far off.'

/baynama kana yanzilani idh samia jarasa al kanisati taazifu nachidan diniyan hinama daqqat assaatu assadisatu/.

/subhanaka allahuma

$$
\text { fi duja }
$$

wasiaat rahmatuka kulla chayiin fi dhuha wa layli idha

saja

wa nahaari idha tajalla

/thumma khafatat annaghamatu watarin baada watarin aan masaamii Ursula fi samain ghabat aani al aayuni ila baladin dahamahu al laylu. Kana dhalika yuchbihu al usuura al ghabira fi qariiha al - khafiti. Kana kullu dhalika baiidan kulla al budi/.

Uppermost in the translator's mind stands the following question: how to render the range of meaning and emphasis, the whole idea and image in prose and verse? The answer to this question requires some meditation upon the magic of the moment. For the enchanted moment ${ }^{12}$ here affects the whole process including the way the prayer, as the verse reads, is phrased and how the two protagonists who seem to be experiencing some mystic transe are portrayed. With 'Minster bells playing a hymn', the spiritual sentiment outweighs everything else and the transition becomes total: the attempt to go beyond ordinary processes of thought and logic into the world of dreams and the subconscious is attested in the following: "the world had become unreal.” D.H. Lawrence is aware of all this and his smooth shift to verse is neither fortutious nor without consequences. Rather, it heralds a significant change in the course of narration as the omniscient narrator recalls past experience not without nostalgia.

In light of the above, every device, be it stylistic, syntactic or otherwise, takes on an extraordinary meaning. Consider tense whose usual function is to construct the time scale of events and delineate the temporal framework as a whole. The preterit as it is employed here supersedes both the progressive and perfective and the juxtaposition of events produces a 'stop-motion-picture' effect as is always the case when action comes to a standstill like that. Still, the words chosen contribute to the overall effect. The contrast on the one hand between night and light (the verse) and on the other 
hand between the unseen sky and the dusky town (the prose) evokes the twilight zone ${ }^{13}$ where two states of existence and feeling meet. The period 'entre chien et loup' as the French would say, usually connotes bewilderment, blurredness and vagueness and is inkeeping with the vague recollections of the dream-world of one's childhood - a great circumscribed reminiscence.

The sentence which comes immediately after does not make sense unless the connoted effect of twilight is seized and duplicated into the target language. Past the traditional functions of words, whether to name a spade a spade or stand for notions by metaphorical extension or reduction, words may act as forerunners. This, incidentally, is analogous to the anticipatory effect created by the 'dumb show', 'dreams' and similar techniques Shakespeare employs to foreshadow future events. Now that words are vested with extra power so as to foreshadow action about to happen, the assessment of lexical choice from diverse perspectives would certainly make it possible to explore new meanings.

For the sake of comparison, let us mention the well-documented parallel between the translator and film producer. Beyond the merely linguistic hurdles translators and film producers alike try to visualize the setting both spatial and temporal to make sure they clearly capture the effect, and duly assess the scope, of words and can transmit it. When called upon to reproduce the scene and the concomitant effects, film makers closely read and re-read the original text and seek for the tiniest element. Translators proceed likewise: they read the text through, perhaps even aloud, lest somewhere in the text some given detail, lexico-grammatical or otherwise, explicit or implicit, might escape their notice.

Although all the countries across the world are closely connected and therefore dependent on each other in every respect, cross-cultural communication remains the most problematic area in translation. Even genetically-related languages continue to diverge over time. Consequently, the translator must strike some balance whether at the level of content, expression, or sound effect.

It is equally important that the translation be a medium of cultural transmission, not merely an empty echo trying to reproduce, more or less mechanically, the original's beat (cf. Raffel 1989, 34). Thus, in the hymn case, the verse abounds in religious and biblical imagery alongside lyrical and poetic overtones. A wise procedure therefore is to delve into the Arabo-Islamic culture and investigate both the Koran and the Hadiith (the Prophet's sayings) so as to ascertain the extent to which night and light are significant, recurrent themes in religious discourse. The translation must be consistent with the Judeo-Christian tradition which precludes pagan imagery, i.e. total exclusion of imagery and thought reminiscent of the pagan era.

In Sura 'The Forenoon' XCIII God swears both by the forenoon (after sunrise) and the nightfall (just after sunset) to assure His prophet He has neither forsaken nor hated him. In Sura 'The Night' XCII, God swears by the nightfall (after getting dark) and takes the oath that he who fears Allah will be duly rewarded. ${ }^{14}$

Past the 'night-light' dichotomy, the translator must be able to recognize that the shift to verse affects the choice of words. The hymn, a reminder of psalms in the Bible, manifestly highlights the solemnity of the moment and echoes a certain call that only meditators can hear. The verse thus sets the tone of the text and signals the character of the translation. Both archaic thee (obj. pron.) and sound effect - be it alliteration or rhyming - pose fewer problems. Thus the initial consonant cluster /gl/ sound as 
available in such phonesthetics as 'glint, gleam, glitter, etc.', soft nasal blessings /m, n/ and liquids /l, r/ evoke glow and dim light respectively. ${ }^{15}$ Translators whether mere amateurs or craftesmen of high renown agree that the sound may be sacrificed but never the meaning save when the sound's contribution to meaning is decisive (cf. the sense of soft breeze and perfumed hush in Hugo (cf. Frame 1989, 72):

"Un frais parfum sortait des touffes d'asphodèle,

Les souffles de la nuit flottaient sur Galgala."

The problem raised is that the attitude vis-à-vis sound, in the main, is arbitrary and varies from culture to culture, which means that sound is after all culturespecific.

A translator-reader must be aware of possible meanings - overt and covert - and possible links - semantic and lexical - between the bells playing a hymn, the tune falling out and the dim, bygone centuries. Music falling out is analogous to time passing by (elapsing) in a number of respects, awoke would not appear as full-blown so long as its relationship with uneasy dreams is not explored and elucidated.

As Gregor Samsa awoke one morning from uneasy dreams he found himself transformed in his bed into a gigantic insect.

/indama istafaqa/ Gregor Samsa /faziaan dhata sabahin aaqba ahlamin muziijatin, adraka annahu qad tahawwala wa huwa la yazalu fi firachihi ila hacharatin mahulatin/.

The last two examples are worth closer examination. ${ }^{16}$ Woke and awoke seem to have conjured up a like image in the mind of all students simply because the Arabic counterpart /istayqadha/ or /istafaqa/ are more or less similar. Lexicographers, however, affirm that no two snowflakes are alike (cf. Rabassa 1989, 1). Alert translators cannot afford to be any more unwary of the semantic subtleties than the untutored reader is. It is stated in the NIWCDE ${ }^{17}$ that however similar in basic meaning, the four verbs, namely awake, awaken, wake, and waken offer a confusing variety of choices in actual use. ${ }^{18}$ Whereas Wake up! is the familiar and homely form in the imperative, the other three would be felt as poetic. In the late seventeenth century awoke emerged, reinforced by analogy with broke. The only difference was that awoke (intr.) would have been preferable for the figurative uses.

In fact, Gregor Samsa, the protagonist, awoke to a new devastating reality ("to find himself...”). That is precisely why Arabic /istafaqa/ here cannot make sense without complement /faziaan/ (frightened) (By way of illustration compare the following: "Kelcey awoke with a groan"; "Old Bleecker awakened. He rolled over and groaned loudly" in Crane 1893, 120 and 121). The interruption of sleep is caused by uneasy dreams. Indeed, preposition from is the element that forges the causal bond and even permits the transition. Should the sentence be approached otherwise (as a speech act in its own right) the investigation would cease to be conducted merely on lexical or syntactic grounds. I shall consider two major approaches with reference to lexical semantics.

(1) Formalists hold that the lexical item is the focus of investigation and that all items in the lexical stock are closely knit. Accordingly, the meanings of the item under investigation should be compared and contrasted with the rest of the lexicon. The emphasis on internal relationships between items in the code leads to the modelling of lexical fields and, ultimately, to the specification of the total lexicon of the language. 
(2) Functionalists focus on concepts/referents and content with the list of words which designate them. In other words, they insist that the semantic is primary whereas the lexical is secondary. The result of such an emphasis leads to the modelling of semantic rather than lexical fields and ultimately, to a contribution to epistemology, i.e., the theory of knowledge (Bell 1991, 116 and cf. ibid. ch. 7 section 7.2.2).

Given the interdependence of the various linguistic fields, i.e., semantics, stylistics, pragmatics, etc., notions such as propositional meaning, illocutionary force, commmunicative import, etc. should be integrated in translating. Unless the focus of interest shifts from word/sentence meaning to the resources the code possesses for the transmission and reception of particular kinds of meaning, translators are bound to fail. The immediate situation represented by the text as a speech event is by no means unusual and therefore can be accommodated within the universe of discourse (Bell, op. cit. 117).

With all this in mind, a translator should demonstrate great resource in dealing with each single case. Consider uneasy dreams (Appendix III) which presents a slightly complicated case. The translator here, no matter how talented, cannot make up her/ his mind and respond tentatively until s/he checks several possible ways. In fact, the translator has little room for manoeuvre: to choose whichever technique s/he deems best suited. For the choice must be consistent with three maxims: 1- to keep as close as possible to the original in form and content (loyalty to the original); 2- to opt for the word or expression most commonly used (use frequency (Newman 1981), probability of occurrence (Bauer 1983) and item familiarity (Mey in Bauer ibid.); and 3- to assess the degree of authenticity of choice (authenticity is crucial). All three maxims should apply in order to determine whether /ahlamin/ (dreams) or antonym /kawabisin/ (nightmares) supersedes in a context such as this. For argument's sake, I would add that in terms of feasibility /ahlamin muziijatin/ (frightening/nightmarish dreams) though oxymoronal will do whereas /kawabisin muziijatin/ for being tautological will not.

Given that the case is rather peculiar, I suggest we rely on the Koran on the ground that it is considered as the final authority, the highest linguistic achievement of the Arabic language that everybody should try humbly to emulate. ${ }^{19}$ In other words, nothing should be written which does not comply with the linguistic, idiomatic and rhetorical conditions obtained in the Koran (cf. Roman 1990, 5 in Gadacha 1998).

Having read through Sura XII, one realizes that only /adhghathu ahlamin/ is available. ${ }^{20}$ The idiosyncratic effect of the combination is obvious even to unwary readers. /adhghathu/ sounds a bit archaic yet by no means pedantic or obsolete. Besides, /ahlam/ (dreams) and /adhghathu/ (mixed-up, false) seem to collocate perfectly. ${ }^{21}$ With /adhghathu ahlamin/ the reproduction of the oxymoronal effect is guaranteed. On the other hand, /ahlam/ (dreams) recall wonderful hopes. This, incidentally, may account for the large number of girls symbolically called /ahlam/: "What's in a name? that which we call a rose/ By any other name would smell as sweet" (Shakespeare, Romeo and Juliet 2.2).

The trouble translating Kafka arises from the fact that realism and surrealism are loosely termed concepts. For instance, there can be no absolute distinction between dreams and reality because the state of dreaming (the event(s) one experiences during sleep) bears and impinges on reality. The inverse is also true. That the two worlds overlap foments chaos. 
Instead of dissipating the confusion, the author asserts It was no dream (pg2). That is the height of absurdity. Although the non-elliptical, declarative sentence is a deliberate exercise in mystification, it allows the narrative to progress. The whole descriptive effort deployed immediately after that statement is meant to enlighten the translator-reader who now has grounds to believe that the metamorphosis is sober truth.

The highly imaginative endeavour to describe the unbelievable in purely physical terms (limbs and parts of the body affected) is presumably a flight of fancy but certainly not a fairy tale since paragraph (2) abounds with realism. The regular bedroom above the table.. and information about the protagonist's identity as a commercial traveller show a shrewd, down-to-earth realism. Even the build-up of the text shows Kafka as a dashing, sometimes bawdy realist. The wonderfully wrought introductory passage and absolutely unique texture are revelatory of his sense of literary consistency. Both the propositional meaning available in the very first line and details about the metamorphosis process proper are offered at once.

The factual description adds to the gritty realism of the situation and Kafka seems simply loathe to take his readers unawares. In addition, he deliberately states in full what he intends to do. How then to render words, text, texture, and meaning propositional or otherwise?

\section{Conclusion}

Recent advances in translation theory have attested to the following: It is extremely difficult, if not impossible, to find a set of data which could prove conclusively exactly when instances of mistranslation occur. The translating exercise is at best biased and the attempt to present a brief account can prevent full appreciation of both the range and quality of the SL text. It may suffice to mention the distinctive functions of the different text conventions, notwithstanding stylistic subtleties and idiosyncracies, which frame language in particular contexts and to which readers respond in different ways. Cross-linguistic, and subsequently cross-cultural, research demonstrate that oneto-one correspondence remains a fanciful concept. Foremost among the breakthroughs in the literature is that any tiniest element, no matter the kind, is all-pervasive. This, somehow, is reminiscent of the 'butterfly effect' that scientists have developed so as to account for nonsensical and chaotic variation.

Nonetheless, despite the disparity ${ }^{22}$ which varies in degree between languages, related and unrelated, it is possible to investigate these languages, obtain a fair understanding of them, and in the long run rejoice in meeting the challenge of translation. Several instances of mistranslation may stem from that disparity. There may be no exact equivalence but this does not imply that translation is doomed to failure though we will never be totally satisfied with the final results.

The following are, in my view, the three concluding remarks - two focal and one peripheral - which make, in isolation or in combination with each other, for the potential failure of the students.

(1) Misreading - certainly the most dangerous pitfall - makes for the translator's failure to appreciate the true worth of lexical choice. The translator-reader must be able to recognize that whichever word a writer chooses to express his/her own feelings or thought contrasts textually with the total inventory of words available, and thereby 
interpret the choice as being subjective. Part of the danger the translator-reader risks comes precisely from the translator her/himself when s/he appropriates the original text.

(2) The ISLT students seem to be surprisingly unaware of the basics of writing as a skill proper. Of the instances of mistranslation encountered several stem from the inability or, presumably, lassitude ${ }^{23}$ of the students to discern the way the ideas are construed and textured. There is no point in accumulating theoretical knowledge if the students are unable to benefit from what they already know - failure to associate, say, aspect or mood whether with wording or structure.

(3) Last but not least, non-linguistic factors may, and often do, account for mere linguistic oddities such as stylistic and lexical deviations - in collocates, in the expected sequence of words, the potential thematic significance of fronting and foregrounding.

“Translatability gains prominence," Wolfgang Iser (2002, 2) writes, "as the various levels appear to be mutually exclusive and yet provide stances for looking at and assessing one another. These levels, then, turn into mirrors for one another, and their mutual refraction translates each level as a figure into the ground of the other one. In this respect, translatability proves to be a counter-concept to the otherwise prevailing idea of cultural hierarchy."

\section{NOTES}

1. The Institut Supérieur des Langues et de Traduction, Tunis-Tunisia.

2. Any discussion of translation in broad terms is dangerous and any discussion of the craft of translation by an individual translator - though less dangerous and perhaps finally more valuable - has to be subjective and limited... The sense of the danger results from the commonplace generalization ascribed to Robert Frost that translation is a form of betrayal. Some would say that translation far from being a betrayal, is in fact a salvation, bringing to the translated text the kind of long life it could not possibly have in the original alone, especially when the original is an obscure language (Keeley 1989, 54).

3. The term text refers to a complete linguistic interaction (spoken or written), preferably from beginning to end. Because the purpose and structure of communicative behaviour cannot be described by looking at only single sentences, systemic linguists look instead at texts, the linguistic products of everyday language events... (cf. Eggins 1994, 5).

Moreover, one can deduce the context of language use from the linguistic patterns in a text. Simply by reading or hearing a text we can figure out so much about its source. Somehow, context is in text: text carries with it, as a part of it, aspects of the context in which it was produced and, presumably, within which it would be considered appropriate (cf. Eggins ibid., 7 and for more details chapter 4).

4. Content and expression are technical labels for the components of the semiotic system. Ferdinand de Saussure $(1959,66)$ was instrumental in formulating the theory of semiotic systems. Parallel to Saussure's signifié (signified) and signifiant (signifier) content and expression refer to the two dimensions which together constitute a sign. Content is encoded in (realized in) expression. Needless to reiterate that the fusion between the two sides of the sign is arbitrary (cf. Eggins op.cit. 14-15).

5. Lexical equivalence does not exist within the same language, let alone across languages. Variation is extant within speakers of the same dialect. Among the significant examples dialectologists offer is the terms fall and autumn. Style is often decisive, e.g. A nasty smell might be in the appropriate setting, an obnoxious effluvium or an 'orrible stink. The former is joculary and 'posh', and the latter colloquial. More importantly, one must be aware of three different layers of meaning words may have: emotive, evaluative and cognitive meanings. Aware of the potential of the emotive meaning of words to influence attitudes, semantics often make a great play with the emotive difference between politician and statesman, hide and conceal, liberty and freedom. There are far more subtle ways than saying something is good or bad. In politics, words are often chosen simply for the effect they are 
likely to have (e.g. Fascist). The meaning of words is not simply a matter of objective facts; a great deal of it is subjective and we cannot clearly distinguish between the two.

Some words are collocationally restricted as they occur only in conjunction with other words. Thus rancid occurs with bacon or butter, addled with eggs or brains. Obviously there is a loose sense of meaning: many words are close in meaning or their meanings overlap. Dictionary-makers exploit this kind of synonymy. Dictionaries tell us little about the precise connections between words and their defining synonyms or between the synonyms themselves. It has been suggested that true synonyms are mutually interchangeable in all their environments. But there are no total synonyms in this sense; indeed this would seem to be a corollary of the belief that no two words have exactly the same meaning... (cf. Palmer 1981, 83-93).

More importantly, idioms can be defined in terms of non-equivalence in other languages.

6. N.B., Advances in lexical semantics attested that the meaning of words can be stated in terms of their association with other words. For semantic division may override word division. Consider, for example, heavy smoker and good singer. Semantically, these are not heavy + smoker (a smoker who is heavy) and good + singer (a singer who is good). The meaning rather is one who smokes heavily or sings well (Palmer ibid. 36).

The choice whether of words, style or code attests to the relevance of context. Code-switching, diglossia, sociolinguistics and stylistics all fall into the (widely defined) area of semantics.

7. The illocutionary force forms the basis for more specific interpretation and makes it possible to check out impossible meanings and infer innermost thoughts. «The interpretive weight... is thus much greater than the linguistic import» (Gumperz op. cit., 150).

8. A translator should not be contemptuous of colloquialisms; instead, s/he must show an insight, a breadth of vision and refute the puristic claims that the vernacular has a derogatory force (cf. Gadacha 1998, 25). In his Rudiments of English Grammar (1761), J. Priestly wrote that language "will never be affected by arbitrary rules of any man, or body of men whatever $[\ldots]$. It must be allowed, that the custom of speaking is the original and only just standard of any language" (in Gadacha ibid. 23).

9. OPEC (Organization of Petroleum-Exporting Countries) is transliterated into /munadhamatu al/ opeq.

10. This in fact is reminiscent of deictics which are always subjective.. while propositions are objective.

11. In practice, however, linguists often attempt to rule out contexts as far as possible - to deal with 'maximally decontextualised sentences' (Lyons 1977, 590). These are the objects of study of most grammars. On methodological grounds this is essential because of the enormous variation in language, and it is difficult to accept, without severe reservations, Chomsky's $(1965,3)$ view that 'linguistic theory is concerned primarily with an ideal speaker-hearer, in a completely homogeneous speech community, who knows its language perfectly' (In Palmer op.cit. 65-66). The dangers are all the more obvious as translation activities are anchored in situational thinking (Biguenet \& Schult (eds) 1989, xii).

12. 'The graceful lyricism of the moment provides inspiration for poets, lovers and prayers (cf. Some 'Enchanted Evening', title of a song written by Oscar Hammerstein II, 1949).

13. 'The Twilight Zone' (title of a television series of horror stories, 1950's).

14. (1) By the forenoon (after sunrise);

And by the night when it is still (or darkens);

Your Lord has neither forsaken you nor hated you.

(2) By the night as it envelops;

And by the day as it appears in brightness...

15 PHONESTHETICS are words "in which one part, often the initial cluster of consonants, gives an indication of meaning of a rather special kind. Thus many words beginning with $s l$ - are slippery in some way - slide, slip, slither, slush, sluice, sludge, etc., or else they are merely pejorative - slattern, slut, slang, sly, sloppy, slovenly, etc. The sk- words refer to surfaces or superficiality - skate, skimp, skid, skim, skin, etc.." But not every word with these phonological characteristics will have the meaning suggested (Palmer op.cit., 35).

16. Although the text is a translation, the difference it makes here is only minimal. For what matters above all is the interaction with text per se. The English version avails me the opportunity to bring into focus, and attest with examples, fundamental aspects in cross-cultural discourse.

17. The New International Webster's Comprehensive Dictionary of the English Language. Deluxe Encyclopedic edition. Trident Press International, 1996 edition.

18. ...Awake and wake have checkered form-histories. In the King James Bible, Shakespeare, and Milton, only the inflected forms in -ed are found. But awake and wake each has a strong verb as well as a 
weak one in its ancestry, and in the late seventeenth century the alternative inflected forms awoke, awoken, and woke, woken emerged, reinforced by analogy with break, broke, broken, etc. These alternative forms have led to uncertainty and confusion in usage. For the past tense of awake, awoke, is usual; awaked tends to be felt as Biblical. Awoke as the past participle is rare, and awaked seems awkward to some; what happens in practice is a borrowing of the past participle from awaken. For wake, the more usual past is woke (or woke up); wake in the intransitive is also standard, but in the transitive sense it is dialectal, referring to holding a vigil or wake... Real uncertainty arises over the form to choose for the past participle of wake. In British (or dialectal American) usage, woken, or, for the phrasal verb, woken up is used: He had woken (or woken up) early. American usage here employs waked (up), or if this is felt as awkward, particularly in the passive, the past participle from waken or awaken: What woke her? She was awakened by (or wakened) by the noise of the crash.

19. It might be argued that excessive use of archaisms including Koranic or Biblical expressions is equated with pedantry and purism. Archaisers who permanently stick to forms and expressions such as used in Old English, Old French, and Old Arabic are accused and often convicted of anachronism (cf. Gadacha 1998).

20. In Sura LII, 32, /ahlamin/ turns into 'minds' as follows: "Do their minds command them this to tell a lie against you or are they people exceeding the bounds."

21. By collocation I mean words that tend to co-occur: "you shall know a word by the company it keeps" (Palmer op.cit. 75-76; for the three collocation restrictions cf. Palmer ibid., 79).

22. We have grounds for suspecting the hypothesis which claims that language determines world vision, i.e., that without language the world has no shape at all. Such an extreme interpretation is untenable for the same kind of reason as is the nominalist view of words as mere names of things. If a speaker of a given language has a different picture of the universe, his picture nevertheless can be related to and in some degreee 'mapped upon' the one that others have.

23. During the first two years, the ISLT devotes a special course to writing skills proper for first and second year students.

\section{REFERENCES}

Bauer, L. (1983): English Word-Formation. Cambridge Textbooks in Linguistics: Cambridge University Press.

BeLL, R.T. (1991): Translation and Translating: Theory and Practice. Longman: London and New York.

Biguenet, J. \& Schulte, R. (Eds.) (1989): The Craft of Translation. The University of Chicago Press: Chicago and London.

Сномsкy, N. (1965): Aspects of the Theory of Syntax. Cambridge, Mass.: MIT Press.

Crane, S. (1893): The World of Maggie. In Katz, J. (ed.). 1969. The Portable Stephen Crane. Penguin Books.

EgGINs, S. (1994): An Introduction to Systemic Functional Linguistics. Pinter Publishers: London.

Frame, D. (1989): "Pleasures and Problems of Translation." In Biguenet, J. \& Schulte, R. (Eds.).

Gadacha, A. (1991): Diglossia: A Case Study of Tunisia. Mémoire de DEA. Université de Nice Sophia-Antipolis.

— 1998. Language Planning and Language Conflict, the case of multilingual Tunisia: Contemporary aspects of status, function, and structure of the languages and language varieties used and sociolinguistics implications of the language shift. Mémoire de Thèse. Université de Nice SophiaAntipolis.

— 1998. «Réflexion sur le rôle des facteurs socioculturels dans l'alternance codique et l'emprunt en Tunisie». In Lafage, S. \& Queffélec, A. (Eds.). Le Français en Afrique. 13 Déc. Didier Erudition.

Gumperz, G.G. (1982): Discourse Strategies. Cambridge: Cambridge University Press.

Halliday, M.A.K. (1985): An Introduction to Functional Grammar. London: Edward Arnold.

Keeley, E. (1989): “Collaboration, Revision, and Other Less Forgivable Sins in Translation.” In Biguenet, J. \& Schulte, R. (Eds.).

Lyons, J. (1977): Semantics. Cambridge University Press. 
Mitchell, T. F. and Al-Hassan, S.A. (1994): Modality, Mood and Aspect in Spoken Arabic with Special Reference to Egypt and the Levant. London: Kegan Paul.

Newmark, P. (1981): Approaches to Translation. Oxford. Pergamon.

— 1988. A Textbook of Translation. Prentice Hall. New York, London, Toronto, Sydney and Tokyo.

Palmer, F.R. (1981): Semantics. CUP: Cambridge.

Peden, M.S. (1989): "Building a Translation, the Reconstruction Business." In Biguenet, J. \& Schulte, R. (Eds.).

Rabassa, G. (1989): “No Two Snowflakes Are Alike: Translation and Metaphor." In Biguenet, J. \& SChulte, R. (Eds.).

Raffel, B. (1989): “Translating Medieval European Poetry." In Biguenet, J. \& Schulte, R. (Eds.).

Robert, S. (1994): «Sur le rôle du sujet énonciateur dans la construction du sens: liens entre temps, aspect et modalité». In YaguelLo, M. (éd.), pp. 209-229.

Roman, A. (1990): Grammaire de l'arabe. Que sais-je? Paris: PUF.

Schramm, A. (1996): “Using Aspect to Express Viewpoint in EST Texts." English for Specific Purposes. 15/2, 141-163.

Upjoнn, J. (2001): Minimum Competence in Scientific English. PUG.

Widdowson, H.G. (1979): “The Deep Structure of Discourse and the Use of Translation." In Widdowson, H.G. Explorations in Applied Linguistics. OUP.

Wolfgang, I. (2002): On Translatibility. <http://www.pum.umontreal.ca/revues/surfaces/vol4/ iser.html>

Yaguello, M. (éd.). (1994): "Subjecthood and Subjectivity. The Status of the Subject in Linguistic Theory ". Proceedings of the Colloquium Subjecthood and Subjectivity: the status of the Subject in Linguistic Theory. London 19-20 March 1993. OPHRYS.

\section{Appendix I}

\section{Rise in Price of Oil Starts to Hurt Asia Drop in Exports is Principal Fear}

The surge in oil prices is starting to hurt Asia, increasing energy costs in many economies and raising fears that growth may slow just as much of the region is rebounding impressively from the financial crisis and recession of 1997 and 1998.

Asian stock markets have fallen sharply in recent days, partly because of concerns that soaring oil prices will dent corporate profits, fuel inflation, force interest rates up and curb growth.

But analysts said Tuesday that the main risk to the region's export-oriented economies was the large potential loss of sales in the United States, Europe, and Japan if a prolonged oil increase undermines demand in any of the world's three major markets.

The Japanese finance minister, Kiichi Miyazawa, implicitly endorsed that view when he said Tuesday in Tokyo that finance ministers and central bankers from the Group of Seven leading industrial powers would discuss the impact of oil prices when they meet in Prague this week-end.

David Fernadez, an economist at J.P. Morgan \& Co., in Singapore, said global demand was clearly being hurt by higher oil prices, raising a central concern for the developing and newly industrialized economies of Asia: the possibility that U.S., Europe and Japanese imports from the region will slow.

"At this point, such an event seems unlikely," he said. "But for a region so reliant on exports, that is emerging Asia's true vulnerability to higher oil prices."

Much of the growth in demand for oil that has pushed prices to 10-year highs has come from Asia, which has to import much of its oil. Rapid industrialization has increased the region's share of global oil consumption to 17 percent from 11 percent in 1990. Oil prices fell 33 cents Tuesday to $\$ 36.55$ a barrel on the New York Mercantile Exchange.

Bill Belchere, chief economist in the Singapore office of Merill Lynche \& Co., said that if oil prices averaged $\$ 36$ a barrel in 2001, it could trim as much as one and a half percentage point of growth from the region as a whole. 
But the impact on Asian countries would be uneven. Indonesia, Malaysia and Brunei - all net exports of oil - would continue to get a boost to their economic growth.

China is partly insulated because it burns a lot of domestically produced coal, although demand for imported oil is rising fast.

Japan, too, is unlikely to suffer much of the higher prices because of its strong currency. Japan has also greatly reduced its dependence on imported oil since the 1970 s by making more efficient use of the fuel and switching to alternative energy sources, such as nuclear power.

Mr. Belchere said that the main losers would be the region's other oil-reliant economies: the Philippines, South Korea, Thailand, Taiwan, Singapore, India and Hong Kong.

The Philippines, Thailand and South Korea have had to raise gasoline and other energy prices by as much as 50 percent in recent months to offset the higher cost of imported oil. This has created a public and political outcry.

Michael Richardson International Herald Tribune

Wednesday, September 20th 2000.

\section{Appendix II}

As they descended, they heard the Minster bells playing a hymn, when the hour had struck six.

'Glory to thee my God this night

For all the blessings of the light -'

So, to Ursula's ear, the tune fell out, drop by drop, from the unseen sky on to the dusky town. It was like dim, bygone centuries sounding. It was all so far off. She stood in the old yard of the inn, smelling of straw and stables and petrol. Above, she could see the first stars What was it all? This was no actual world, it was the dream-world of one's childhood - a great circumscribed reminiscence. The world had become unreal. She herself was a strange, transcendent reality.

They sat together in a little parlour by the fire.

'Is it?' she replied, laughing, but unassured.

'What?'

'Everything - is everything true?'

'The best is true,' he said, grimacing at her.

'Is it?' she replied, laughing, but unassured.

She looked at him. He seemed still so seperate. New eyes were opened in her soul. She saw a strange creature from another world in him. It was as if she were enchanted, and everything were metamorphosed. She recalled again the old magic of the Book of Genesis, where the sons of God saw the daughters of men, that they were fair. And he was one of these, one of these creatures from the beyond, looking at her, and seeing she was fair.

Women in Love D.H. Lawrence

\section{Appendix III}

As Gregor Samsa awoke one morning from uneasy dreams he found himself transformed in his bed into a gigantic insect. He was lying on his hard, as it were armour-plated, back and when he lifted his head a little he could see his dome-like brown belly divided into stiff arched segments on top of which the bed-quilt could hardly keep in position and was about to slide off completely. His numerous legs, which were pitifully thin compared to the rest of his bulk waved helplessly before his eyes.

What has happened to me? he thought. It was no dream. His room, a regular human bedroom, only rather too small, lay quiet between the four familiar walls. Above the table on which a collection of cloth samples was unpacked and spread out - Samsa was a commercial traveller - hung the picture which he had recently cut out of an illustrated magazine and put into a pretty gilt frame. It showed a lady, with a fur cap on and a fur stole, sitting upright and holding out to the spectator a huge fur muff into which the whole of her forearm had vanished.

Franz KAFKA METAMORPHOSIS

(Translated by Willa and Edwin Muir, Penguin Books 1984). 